ficial attainments. The medical pupil and the medical profession will scarcely be raised, the former in public estimation, the latter in social rank, by following the Manual system of education advocated by this "friend," whom I willingly leave to his vulgarity and folly, whilst $I$ again appeal to those who have the power, and urge them to select such works on which to examine our students as are worthy of our profession; such works as those of Harvey and of Bell; such works as those of Mïller and of Louis.

I certainly think that all our students ought to know the Latin and the French languages well, however they may be enamoured of their "native tongue," and I would examine them in Celsus and some French medical classic. I think, too, that they should know enough of Greek to muderstand the etymology of the terms which they will have to pronounce every day of their lives: and I will add my conviction, that if they do so, they will take a higher standing in society, and occupy a better position amongst the gentry and clergy of the county in which it may be their lot to practise, than if they be ignorant and illiterate. They will then, also, insure their individual success, and raise and grace their profession.

Let our students themselves weigh this well, and consider whether any advantage can accrue from the superficial knowledge conveyed by the writers of Manuals. Let them well weigh the style of their "friend," the admirer of these writings. Let them ask themselves whether that style be dignified or gentlemanly. "A Looker-On" gravely and seriously, and conscientiously, means what he says. Can this be imagined of the "friend"? I leave this question to all whom it may concern.

I, at least, should like to see our students something like those of Oxford and Cambridge, taking, on entering upon practice, the rank of scholars and gentlemen. They ought to be, in natural and medical sciences, what the clergy are in the classics. But in order to compass this, they must do as the clergy do, read the classics of the profession. Was any clergyman ever content with reading a Delectus or Analecta?

I am glad to find that my former note has excited some attention, and I will still hope to see our present trumpery medical books replaced by our medical classics, and encouragement given to original observers and authors.

The information contained in the letter of Justimis is indeed most melancholy.-I am, Sir, your obedient servant,

London, May, 18:7. A LOOKER-ON.

\section{DISCOVERY OF THE APPLICATION OF ETHER TO SURGICAL OPERATIONS. To the Editor of The LANcet.}

SIR,-As your remarks, under the head of "Correspondence," in "THE LANCET" of May 8th, are calculated to do great injury to the interests and rights of Dr. Morton and Dr. Jackson, will you do me the favour to publish the following brief reply:-

real question seems to be-Did Mr. Horace Wells perform any operation upon a patient under the influence of sulphuric ether prior to Dr. Morton? This has yet to be answered ?"

This question must be answered by Mr. Wells, and Mr. Wells must, when he answers, prove, not merely an operation, but a successful operation, before he can advance any claim to meritorious discovery; and if successful, he must satisfactorily account for his not making the important discovery public. Moreover, before he can interfere in the slightest degree with the merit of Dr. Morton and Dr. Jackson, who did make public the powers of ether, he must show that they were indebted to him for the suggestion. This $\mathrm{Mr}$. Wells does not pretend, and they expressly deny; so that whatever may have been Mr. Wells's private experiments, Dr. Morton and Dr. Jackson must continue to be considered original discoverers, until some evidence is produced to the contrary.

“That the entire subject of preventing pain in surgical operations had been occupying Mr. Horace Wells's mind, and that he had lectured publicly in Boston on the subject, is pretty well proved."

It had occupied Mr. Wells's mind, (so also it had occupied Dr. Collyer's mind.) This is admitted by Dr. Morton and Dr. Jackson; but they deny that the fact of the subject having occupied Mr. Wells's mind, and of his having lectured upon it, entitle Mr. Wells to the merit of discoveries made by them. 'There may be merit in seeking, but the reward is to him who finds. Mr. Wells sought the means of preventing pain in surgical operations-Dr. Morton and Dr. Jackson found them. Mr. Wells imagined, and still imagines, nitrous oxide gas to furnish the means-Dr. Morton and Dr. Jackson make no claim to the discovery of any such powers in nitrous oxide gas, and desire that the honour of it should be shared. by Mr. Wells and Sir Humphry Davy.

"That in the account of their proceedings, Dr. Jackson and Dr. Morton should have made no mention of Mr. Wells is most extraordinary, and must tend to create a powerful prejudice against both the names of Dr. Jackson and Dr. Morton."

It was entirely unnecessary for Dr. Morton and Dr. Jackson to make mention of Mr. Wells; for it must be remembered that Mr. Wells tried his experiments with nitrous oxide gas, and publicly lectured upon it in Boston, the place of residence of Dr. Morton and Dr. Jackson; and that, consequently, all the processes, proceedings, and opinions of Mr. Wells upon the subject were as well known to the whole medical profession of Boston as they were to Dr. Morton and Dr. Jackson themselves. It would have been extraordinary if they had made mention of Mr. Wells, agreeing as they did with the universal opinion in Boston, that Mr. Wells's ideas upon the subject were useless and impracticable.

So soon as Dr. Norton had ascertained and perfected the process of employing the vapour of ether to prevent pain in surgical operations, he wrote to Mr. Wells upon the subject; and I here subjoin a copy of Mr. Wells's reply:-

Dr. Morton :

" Hartford, (Conn.,) Oct. 20th, 1846.

"DEAR SrR,-Your letter, dated yesterday, is just received, and I hasten to answer it, for fear you will adopt a method, in disposing of your rights, which will defeat your object. Before you make any arrangements whatever, I wish to see you. I think I will be in Boston the first of next week probably Monday night. If the operation of administering the gas is not attended with too much trouble, and will produce the effect you state, it will, undoubtedly, be a fortune to you, provided it is rightly managed.-Yours, in haste,

\section{"H. WeLLs."}

The admissions of this letter, taken in connexion with what has heretofore been published in THe Lavcer of March 13th, are conclusive and fatal to the pretensions of Mr. Horace Wells.-I am, Sir, your obedient servant,

Duke-street, St. James's, May, 1847.

JAMES A. Dorr.

\section{THE MEDICAL REGISTRATION BILL.}

DEAR SIR,-The profession ought to thank you as one man for your " Medical Bill."

This day I forward two petitions to the House of Commons, for presentation at your earliest convenience. I had intended to send them to the Hon. H. Liddell, M.P. for Durham county, but thought better of it, because we were both members of the "National Institute," and think with you, that the "Council" has betrayed its trust, and that its advertisement is a mass of "misrepresentation and falsehood." I have this day written to Geo. Ross, Esq., Secretary, to erase my name from the list of members of the National Institute, as also the names of Alex. Macgregor, M.R.C.S. Edin., and Mr. Muller, M.D. and M.R.C.S. Edin.; and I have promised Mr. Ross to send him three other secessions in a few days, and have told him that all these gentlemen joined the Institute, and paid their money, in consequence of my representations as to the object of the Association; but as the Council has changed its tactics without consulting its constituents, I have only to beg my friends' pardon for wheedling them into a claptrap association, the object of which it appears I have misunderstood.I am, Sir, together with my other friends, "late members of the National Institute," yours, very much obliged, Durham, May, 1847 .

WM. Bishop.

P.S.-You are at liberty to make any use you please of this communication.

\section{MEDICAL REGISTRATION BILL.}

\section{PETITIONS IN FAVOUR.}

Owing to an error of the printer, the petitions from the following gentlemen were enumerated in the last LANCET, as against instead of in favour of the Bill:-

James Espier, Falkirk, Stirlingshire; William Favell, 105, Norfolk-street, Sheffield; Thomas Wood Foster, Ecclesfield, near Sheffield; Robert Roper, 85, WestBar, Sheffield; James Walker, 16, Union-street, Sheffield; Henry Thomas, 79 , Norfolk-street, Sheffield; Arthur Gaved, St. Mabyn, Cornwall; John Deakin, Howard-street, Sheffield; E. D. L. Gillott, 264, Glossop-road, Sheffield. 